\title{
The Rivers Ran Backward: The Civil war and the Remaking of the American Middle Border
}

Review Number: 2051

Publish date: Thursday, 19 January, 2017

Author: Christopher Phillips

ISBN: 9780195187236

Date of Publication: 2016

Price: $£ 22.99$

Pages: 528pp.

Publisher: Oxford University Press

Publisher url: https://global.oup.com/academic/product/the-rivers-ran-backward-9780195187236

Place of Publication: Oxford

Reviewer: Robert J. Cook

In 1850 Abraham Lincoln's most celebrated rival, Stephen Douglas of Illinois, delivered an impassioned speech in the United States Senate. 'There is a power in this nation ...,' he averred, 'That power is the country known as the great West - the Valley of the Mississippi, one and indivisible from the gulf to the great lakes, and stretching on the one side and the other, to the extreme sources of the Ohio and Missourifrom the Alleghanies [sic] to the Rocky mountains. There, sir, is the hope of this nation - the resting-place of the power that is not only to control, but to save the Union ... This is the mission of the great Mississippi valley, the heart and soul of the nation and the continent'. $(1)$

In the end no amount of western chest-thumping could resist the polarising forces of the 1850s. The resulting Civil War of 1861-5 was messy as well as bloody. It was certainly at its messiest in the border slave states of Kentucky and Missouri. Neither of these states seceded from the Union to join the breakaway Confederacy and both mustered more Federal volunteers than Rebels. In this important new book, Christopher Phillips attempts to answer an intriguing question. Why was it that by the end of the 19th century these antebellum 'western' states - polities that had much in common with their free-state neighbours above the Ohio River - regarded themselves, and were regarded by outsiders, as southern, whereas Illinois, Indiana, and Ohio were defined as northern? He finds the answer, first, in the testing wartime experiences of the people living in the slave and free portions of what he calls 'the American Middle Border,' and, second, in the strikingly different commemorative practices of those residents after 1865. 'Loss as much as victory...', he concludes, 'defined the new regionalism on both sides of the rivers'. By 1900 two new regions had been created by 'exclusivist politics that imagined as much as they had experienced the war. The national confluence once represented by the West was remade as South and North' (p. 338).

The book breaks down easily into three non-delineated parts. Part one (chapters one to three) details the history of the middle border before the Civil War; part two (chapters four to seven) assesses the war's impact on the region; and part three, chapter eight, explains the shift to a North-South binary divide in the late 19th century. Throughout the discussion Phillips makes it clear that the rivers referred to in the title of his book are metaphorical as well as actual ones. Fast-flowing streams of war-driven politics, racial violence 
and historical memory refashioned the broadly unified middle border into two culturally distinct American regions.

In part one Phillips argues forcefully that the existence of slavery in two of his five states did not initially divide the white settlers who moved into the region in the early national period. Taking his cue from a previous generation of historians including V. Jacques Voegeli and Eugene Berwanger, he argues convincingly that colour prejudice transcended any notional boundary between free and slave states. Illinois, Indiana and Ohio may have been the fruit of the 1787 North West Ordinance that barred slavery above the Ohio River, but many of their residents proved reluctant to see the back of the 'peculiar institution'. In 1824, for example, the Illinois legislature sanctioned a referendum on calling a constitutional convention to retain slavery. Although the proposition was defeated with the assistance of Virginia-born governor Edward Coles, there were still 331 slaves in the state as late as 1840, many of them the property of Kentuckians and Missourians. Phillips observes that hostility to slavery in the 1830s and 1840s was concentrated mainly in areas of the New England diaspora, most notably the Western Reserve around Cleveland, and that several leading abolitionists in this period actually hailed from the slave state of Kentucky. Most residents of the middle border had little interest in slavery as a moral issue and even less in providing free blacks with equal rights. The free states of the region all passed legislation to curb black in-migration and prevent persons of colour from sitting on juries, serving in militias and voting. Mainstream parties fought battles during this period not primarily over slavery but over whether federal government assistance for infrastructural development was a good or a bad thing.

Party conflict over slavery extension in the 1850 s began what proved to be a disastrous process of sectionalisation for the people of the middle border. Yet even during this turbulent decade, notes Phillips, most whites in the region eschewed radicalism. Although the rise of the anti-southern and anti-slavery Republican Party played a major role in polarising national politics, Phillips contends that the ideological gap between Lincoln and Douglas during their famous debates in Illinois in 1858 was relatively small. Both men claimed the mantle of Henry Clay, the slaveholding Whig leader from Kentucky who had dampened sectional passions thrice in his eventful congressional career, while Lincoln's 'reasoned racialism' and Douglas's 'overtly racist rhetoric' concealed the fact that 'their arguments were often parallel' (p. 102). During the tense secession crisis of 1860-1 support for the Republicans ebbed away in many parts of the region's free states, while demands for peaceable compromise swelled on both sides of the Ohio.

Phillips is at his best in part two where he describes the appalling impact of civil war, "wolfish war - less to be won or lost than endured or survived' - on the middle border (p. 170). Although the conflict afflicted the free states by dividing anti-war Democrats and pro-war unionists in the southern counties of Illinois, Indiana and Ohio, its worst effects were felt in the border slave states. Here, the majority of whites were conditional unionists hoping to avoid being caught up in the spiralling violence between Federal and Confederate forces. Their hopes were dashed by northern and southern military authorities, abetted by local hardliners on both sides, who saw no virtue in lukewarm support for their respective cause or, in the case of Kentucky, Swissstyle neutralism. Phillips is particularly critical of Federal leaders like President Lincoln and some of his western military commanders for drawing a clear line in the region between loyal unionists and treasonous Confederates. Hard-war policies, he argues, such as the confiscation of property, ad hoc declarations of martial law, the imposition of coercive loyalty oaths, and wholesale arrests, proved counterproductive because they induced many conditional unionists who regarded themselves as 'southerners of culture' to become 'political southerners' by rendering overt or covert support for the proslavery Confederacy (p. 132).

The most controversial hard-war policy of all was emancipation which, contends Phillips, finally splintered 'the western consensus' and drove 'a wedge' between free and slave-state residents (p. 211). The division was not at first a clear one. Emancipation received little support in the lower 'butternut' tiers of the free states. Hundreds of Federal officers and soldiers from these counties, especially the many Democrats among them, resigned from the Union army after Lincoln issued his emancipation proclamations in 1862 and 1863. Two Illinois regiments virtually ceased to exist as a result of mutiny and desertion. But the scale of hostility toward abolition in the wake of these edicts was much greater in the slave than the free states of the middle 
border because the majority of white Missourians and Kentuckians could not imagine living in a society in which blacks dwelt among them as free men and women. Phillips argues convincingly that emancipation was closely linked to a rise in guerrilla violence in both his slave states. Guerrillas targeted draft officials and unionist legislators and burned scores of courthouses to the ground. Lincoln's decision in 1863 to muster blacks into the United States armed forces further enraged whites hostile to emancipation. 'Waves of racialized guerrilla violence', writes Phillips, swept the lower border, intensifying Federal hard-war policies and bringing black enlistment to a virtual halt in Missouri by the summer of 1864 (p. 261).

White women were both 'participants and victims in this shadow warfare' (p. 262). They suffered as refugees, as the victims of guerilla depredations and, in the case of slaveholding women, as the objects of intense Federal suspicion. The 1863 Lieber Code defined women who offered succour to the Confederacy as 'quasi-combatants' (p. 263). As a result hundreds were incarcerated in prisons in Louisville and Newport, Kentucky, or banished to the Confederacy. Women furnished material aid to regular and irregular forces on both sides and contributed to the backlash against emancipation. Perhaps because of the paucity of reliable sources Phillips has relatively little to say about the wartime experiences of black women. But he is surely right to observe their inability to protect themselves and their children from angry whites opposed to emancipation and from insensitive treatment at the hands of United States military authorities who crowded vulnerable black civilians into insanitary refugee camps.

The book's final part demonstrates the importance of post-war cultural politics, grounded in these searing wartime experiences, in cementing the destruction of the antebellum western consensus. Bolstered by persistent racial violence during Reconstruction, white supremacist Democrats seized political control of Kentucky and Missouri. Their victory, combined with widespread local white hostility to equal rights for freed blacks, provided the perfect environment for Confederate commemorative practices. White women belonging to Ladies' Memorial Associations and, later, the United Daughters of the Confederacy joined with Rebel veterans in seizing the mnemonic initiative from former unionists, many of whom were disenchanted with emancipation and congressional Republican support for equal rights. The result was what historian Gaines Foster called 'the Confederate tradition,' a remarkably durable and heavily politicised historical memory that rendered both Kentucky and Missouri bastions of the South's Lost Cause.(2) Meanwhile Union veterans in the old free states formed their own groups like the Grand Army of the Republic which commemorated their unique civic service and sacrifice and disseminated the somewhat false impression that Illinois, Indiana and Ohio had always been bulwarks of the free North rather than, as Douglas had put it, 'the great West'.

This book has many strengths, most of which stem from the author's refusal to endorse binary accounts of the Civil War. The result is, by his OUP editor's admission, a 'sprawling' work, but one that conveys superbly the damage done by war to the diverse residents of a no less sprawling region that had once had grand hopes of saving the republic from the disastrous consequences of sectional conflict (p. xi). However, there are flaws. Phillips creates something of a straw man when he claims that 'historians of the sectional crisis commonly portray the federal Fugitive Slave Act of 1850 ... as having awakened a somnolent North to the dangers of a "slave power" conspiring to spread the peculiar institution to the western territories' (p. 88). This isn't my opinion nor is that of political historian Michael Holt whose influential Political Crisis of the 1850s is not cited in the otherwise impressive bibliography.(3) Most northerners were not 'awakened' to the idea of a slave power plot until Douglas introduced his fateful Kansas-Nebraska bill into Congress in 1854. Phillips errs too in contending that Republicans controlled 'all branches' of the federal government when they came to power in 1861 (p. 122). They certainly did not control the Supreme Court and their power in the Senate was enhanced greatly by the withdrawal of so many slave-state delegates. This mistake has serious implications, for his statement imparts greater legitimacy to the secessionist cause than it deserves. The same is true of his debatable claim that 'the federal government's coercion of states, more than the question of slavery, most threatened the nation's stability' at this time (p. 122). The greatest threat to national stability surely came not from the Lincoln administration but from the creation of the Confederacy in February 1861. Equally dubious is his suggestion that in December 1860 South Carolina 'voted unanimously to exercise a state's ultimate right to withdraw from the Union' (p. 108). In saying this the 
author implies that South Carolina actually possessed the right to secede. But, of course, therein lay the rub. Such a 'right' was not enumerated in the Constitution and was vigorously denied by northern unionists like Abraham Lincoln.

At an early stage of the book the author announces that he is descended from slaveholding Kentucky neutralists who opposed the 13th Amendment abolishing slavery in the United States (p. 6). This revelation may help to explain his impressive empathy for, and predominant focus on, the people of the border slave states. Phillips's account has a distinctly neo-revisionist feel to it. In common with an older generation of historians like Avery Craven and George Fort Milton, he clearly (and with good reason) laments the impact of the Civil War on the United States in general and his own region in particular. This approach enables him to deliver a fine account of the conflict's devastating impact on the middle border, but hinders him from considering a point made robustly during the late 1940s by Arthur Schlesinger, Jr., that slavery was a genuine moral evil that required elimination.(4) He is an especially harsh critic of the Republicans for sectionalising political debate in the 1850s and for advocating hard-war policies in the war itself. Greater empathy for what, in this book, are the rather shadowy Republicans of the upper middle border would have enabled him to paint a more nuanced picture of the sectional conflict. Indeed, had he incorporated the state of Iowa into his analysis, his interpretation of events could have been very different.

There is no obvious reason why Phillips could not have included the free state of Iowa in his definition of the middle border. Hamlin Garland, a well-known 'regionalist' writer, spent much of his early life in the state and titled his 1917 autobiography A Son of the Middle Border. Iowa lies north of the slave state Missouri, just as Illinois, Indiana, and Ohio lie above Kentucky. Its lower-tier counties were settled by large numbers of white southerners in the antebellum period, as were the southern portions of these other western free states. It was similarly dominated by white-supremacist Democrats until passage of the KansasNebraska Act. Robert Dykstra's Bright Radical Star (1993) demonstrated how anti-slavery activists in Iowa, many of them devout Quakers and New England Congregationalists, joined forces with pragmatic politicians to seize control of the state government from the Democrats and, in 1868, secure a popular vote in favour of the enfranchisement of local blacks.(5) For many, though certainly not all, of these crusading Republicans, slavery and racial prejudice were sins that sapped the health of the nation. Although their radicalism may have contributed to the onset of the violence that Phillips describes, they had good reason to regard human slavery and racial prejudice as repellent. What was a real dilemma for many white residents of the middle border (Lincoln provides a good example) is also a dilemma for modern scholars who know that only a bloody civil war could have ended slavery in the United States as early as the 1860s. This book would have been strengthened by a clearer acknowledgment of that quandary. It is, nonetheless, essential reading for anyone interested in the American Civil War and its unforeseen consequences.

\section{Notes}

1. Robert W. Johannsen, The Frontier, the Union, and Stephen A. Douglas (Urbana, IL, 1989), p. 85 Back to (1)

2. Gaines M. Foster, Ghosts of the Confederacy: Defeat, the Lost Cause, and the Emergence of the New South (New York, NY, 1987), pp. 4-5.Back to (2)

3. Michael F. Holt, The Political Crisis of the 1850s (New York, NY, 1978).Back to (3)

4. Arthur M. Schlesinger, Jr., 'The cause of the Civil War: a note on historical sentimentalism', Partisan Review, 16 (Oct. 1949), 969-81.Back to (4)

5. Robert R. Dykstra, Bright Radical Star: Black Freedom and White Supremacy on the Hawkeye Frontier (Cambridge, MA, 1993). Back to (5)

Source URL:https://reviews.history.ac.uk/review/2051 
Links

[1] https://reviews.history.ac.uk/item/206074 